\title{
Paenibacillus residui sp. nov., isolated from urban waste compost
}

\author{
Correspondence \\ Célia M. Manaia \\ cmmanaia@esb.ucp.pt
}

\author{
Ivone Vaz-Moreira, ${ }^{1,2}$ Vânia Figueira, ${ }^{1}$ Ana Rita Lopes, ${ }^{2}$ Rüdiger Pukall, ${ }^{3}$ \\ Cathrin Spröer, ${ }^{3}$ Peter Schumann, ${ }^{3}$ Olga C. Nunes ${ }^{2}$ and Célia M. Manaia ${ }^{1}$
${ }^{1}$ Escola Superior de Biotecnologia, Universidade Católica Portuguesa, 4200-072 Porto, Portugal
${ }^{2}$ LEPAE - Departamento de Engenharia Química, Faculdade de Engenharia, Universidade do Porto, 4200-465 Porto, Portugal
${ }^{3} \mathrm{DSMZ}$ - Deutsche Sammlung von Mikroorganismen und Zellkulturen GmbH, Inhoffenstraße 7B, D-38124 Braunschweig, Germany

\begin{abstract}
Two bacterial strains, MC- $246^{\top}$ and MC-247, were isolated from municipal urban waste compost and characterized by a polyphasic approach. Both isolates were Gram-stain-variable, endosporeforming rods that were catalase-, oxidase- and $\beta$-galactosidase-positive, and able to grow at 25$50{ }^{\circ} \mathrm{C}$ and $\mathrm{pH} 7.0-9.0$, with optimum growth at $37{ }^{\circ} \mathrm{C}$ and $\mathrm{pH}$ 7. The predominant cellular fatty acids were anteiso- $C_{15: 0}$, iso- $C_{15: 0}$, iso- $C_{16: 0}$, anteiso- $C_{17: 0}$ and iso- $C_{17: 0}$; the major respiratory quinone was menaquinone MK-7; the cell wall peptidoglycan was of type $\mathrm{A} 1 \gamma$; and the DNA G + C content was 49 mol\%. These characteristics, as well as data from 16S RNA gene sequence analysis, showed that these strains were affiliated with the genus Paenibacillus; the type strains of Paenibacillus ginsengarvi and Paenibacillus hodogayensis were among their closest neighbours ( $<94.2 \%$ sequence similarity). Nevertheless, the hypothesis that strains MC$246^{\top}$ and MC-247 could represent a novel species was supported by the low $16 \mathrm{~S}$ rRNA gene sequence similarity values shared with other members of the genus Paenibacillus and by the observation of distinct biochemical and physiological traits. Strains MC-246 ${ }^{\top}$ and MC-247 shared $99.6 \%$ 16S rRNA gene sequence similarity and showed almost identical MALDI-TOF mass spectra, but could be distinguished at the phenotypic and genotypic level. However, DNADNA hybridization between strains $M C-246^{\top}$ and $M C-247$ resulted in values above $70 \%$ indicating that both organisms represent a single species, for which the name Paenibacillus residui sp. nov. is proposed; the type strain is MC-246 ${ }^{\top}\left(=\mathrm{DSM} 22072^{\top}=\mathrm{CCUG}_{57263^{\top}}\right)$.
\end{abstract}

Composting is a process of biological decomposition, nowadays considered the best process for the treatment of the organic fraction of urban waste (Fehr, 2007). At the end of the treatment, the organic matter is converted into a stabilized humus-like product (compost) that is frequently used in gardening and agriculture. In this study, two bacterial strains isolated from municipal urban waste compost were characterized and identified as members of the genus Paenibacillus (Vaz-Moreira et al., 2008). At the time of writing, the genus Paenibacillus proposed by Ash

Abbreviation: MALDI-TOF, matrix-assisted laser-desorption/ionization time-of-flight.

The GenBank/EMBL/DDBJ accession numbers for the $16 \mathrm{~S}$ rRNA gene sequences of strains $M C-246^{\top}$ and MC-247 are FN293173 and FN293174, respectively.

A phylogenetic tree based on 16S rRNA gene sequences, EcoRI RiboPrints, RAPD profiles and a dendrogram generated by the BioTyper software showing MALDI-TOF MS similarities of strains MC-246 ${ }^{\top}$ and MC-247 and related strains are available with the online version of this paper. et al. (1993) comprises more than 100 species with validly published names (Euzéby, 1997) and includes isolates from a wide variety of habitats, such as soil, sediments and compost, water, plant rhizosphere, food, diseased insect larvae, faeces and human fluids. Members of the genus Paenibacillus are facultatively anaerobic or strictly aerobic, rod-shaped, Gram-positive, -negative or -variable, motile, endospore-forming bacteria with swollen sporangia (Shida et al., 1997). Relevant chemotaxonomic markers of this genus are a genomic DNA $\mathrm{G}+\mathrm{C}$ content of 39.0$55.8 \mathrm{~mol} \%$, the presence of menaquinone MK-7 and peptidoglycan of type A1 $\gamma$ (Shida et al., 1997).

Strains MC- $246^{\mathrm{T}}$ and MC-247 were isolated from municipal urban waste compost produced from undifferentiated urban waste (Vaz-Moreira et al., 2008) and purified by subculturing on plate count agar [PCA (Pronadisa), containing $\left(\mathrm{g} \mathrm{l}^{-1}\right)$ : tryptone, 5; yeast extract, 2.5; glucose, 1; agar, 15]. Cultures were incubated at $30{ }^{\circ} \mathrm{C}$ and preserved at $-80{ }^{\circ} \mathrm{C}$ in nutrient broth with $15 \%(\mathrm{v} / \mathrm{v})$ glycerol. The strains under study were characterized for 
their phenotypic and chemotaxonomic features. The type strains of closely related species (Paenibacillus hodogayensis DSM $22253^{\mathrm{T}}$ and Paenibacillus ginsengarvi DSM $18677^{\mathrm{T}}$ ) were assayed in parallel to minimize differences due to experimental conditions. Colony and cell morphology, Gram-stain reaction, cytochrome $c$ oxidase and catalase activities, endospore production and motility were analysed based on the methodologies of Murray et al. (1994) and Smibert \& Krieg (1994). Unless otherwise stated, all biochemical and physiological tests were performed as described previously (Vaz-Moreira et al., 2007). Biochemical and nutritional tests were assayed using API 20E, API 20NE, API $50 \mathrm{CH}$ and API ZYM strips (bioMérieux) following the manufacturer's instructions. The Voges-Proskauer test was also assayed in methyl red/Voges-Proskauer medium (Oxoid) incubated at $30{ }^{\circ} \mathrm{C}$ for $48 \mathrm{~h}$. Hydrolysis of Tween 80 and starch was performed as described by Tiago et al. (2004). Casein hydrolysis and urease activity were assayed as described by Smibert \& Krieg (1994). Antimicrobial susceptibility and RAPD profiles (with primers M13 and OPA3) were assayed as described previously (Ferreira da Silva et al., 2006).

Determination of the genomic DNA $\mathrm{G}+\mathrm{C}$ content and analysis of respiratory quinones were performed as described previously (Vaz-Moreira et al., 2007) using the methods of Mesbah et al. (1989) and Tindall (1989), respectively. The cellular fatty acid composition was analysed as described by Kämpfer \& Kroppenstedt (1996). All strains were cultivated for 2 days on tryptic soy agar at $30{ }^{\circ} \mathrm{C}$.

Purified peptidoglycan preparations were obtained after disruption of cells by shaking with glass beads and subsequent trypsin digestion (Schleifer \& Seidl, 1985). The amino acid and peptide compositions of peptidoglycan hydrolysates $\left(4 \mathrm{M} \mathrm{HCl}, 100{ }^{\circ} \mathrm{C}\right.$ for $16 \mathrm{~h}$ and $0.75 \mathrm{~h}$, respectively) were analysed by one- and two-dimensional TLC on cellulose plates using previously described solvent systems (Rhuland et al., 1955; Schleifer \& Kandler, 1972).
The nucleotide sequence of the 16S rRNA gene was determined after PCR amplification of total DNA extracts as described previously (Ferreira da Silva et al., 2007). The 16S rRNA gene sequence was compared with others available in GenBank/EMBL/DDBJ using the FASTA package from EMBL-EBI (http://www.ebi.ac.uk). Phylogenetic analysis was conducted using the software BioNumerics (version 5.1; Applied Maths). Sequence relatedness was estimated based on the model of Jukes \& Cantor (1969) and the dendrogram was recreated using the neighbour-joining method. Other methods, namely maximum-parsimony and maximumlikelihood, were applied to assess the tree stability. Nonhomologous and ambiguous nucleotide positions were excluded from the calculations. For spectroscopic DNADNA hybridization, DNA was isolated using a French pressure cell (Thermo Spectronic) and was purified by chromatography on hydroxyapatite as described by Cashion et al. (1977). DNA-DNA hybridizations were carried out as described by De Ley et al. (1970) under consideration of the modifications described by Huß et al. (1983) using a model Cary 100 Bio UV/VIS-spectrophotometer equipped with a Peltier-thermostatted $6 \times 6$ multicell changer and a temperature controller with in situ temperature probe (Varian). Fully automated ribotyping of EcoRI-digested samples was performed with a RiboPrinter system (DuPont Qualicon) as described by Bruce (1996). Analysis by matrix-assisted laser-desorption/ionization time-of-flight (MALDI-TOF) mass spectra of strains MC- $246^{\mathrm{T}}$ and MC-247 and close phylogenetic relatives was performed according to the method described by Tóth et al. (2008).

The 16S rRNA gene sequence analysis revealed that strains MC- $246^{\mathrm{T}}$ and MC-247 had a similarity of $99.6 \%$ and shared $93.7 \%$ similarity with the type strain of $P$. hodogayensis and 94.2 and $93.8 \%$ similarities with the type strain of $P$. ginsengarvi, respectively (Fig. 1, Supplementary Fig. S1, available in IJSEM Online). Results of the phenotypic characterization of strains MC-246 ${ }^{\mathrm{T}}, \mathrm{MC}-247, P$. hodogayensis DSM $22253^{\mathrm{T}}$ and P. ginsengarvi DSM $18677^{\mathrm{T}}$ are presented in

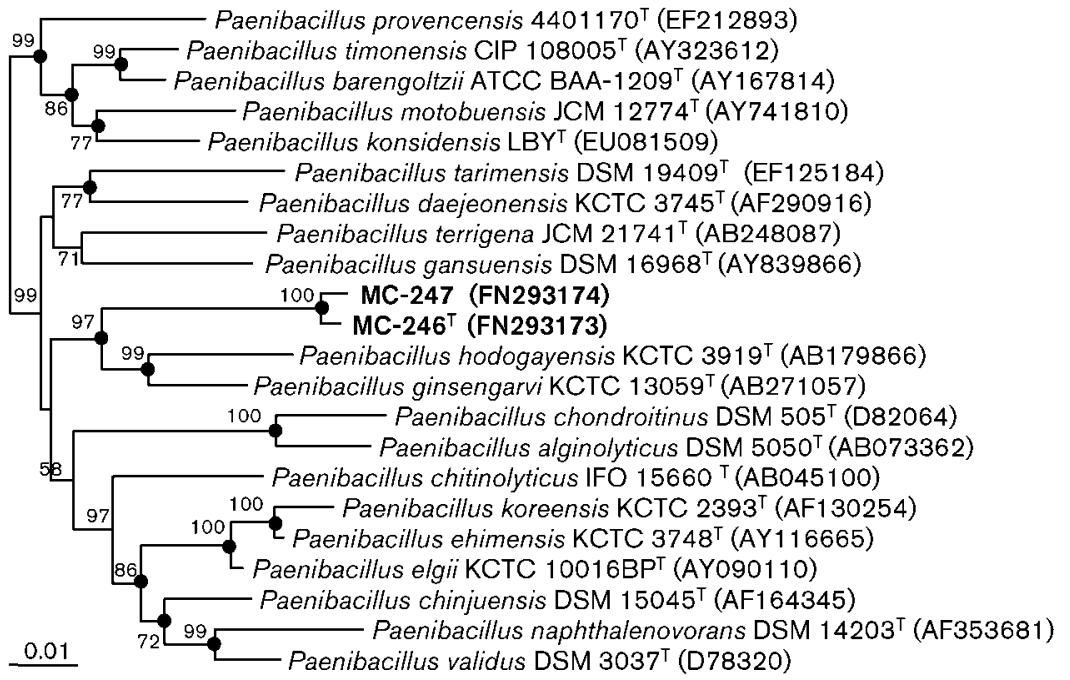

Fig. 1. Phylogenetic tree derived from $16 \mathrm{~S}$ rRNA gene sequence analysis showing the relationship of strains $\mathrm{MC}-246^{\top}$ and $\mathrm{MC}-247$ with members of the genus Paenibacillus. The tree was generated by the neighbour-joining method and bootstrap values $(\geqslant 50 \%)$ generated from 1000 resamplings are indicated at branch points. Filled circles indicate branches also recovered by the maximum-likelihood method. Bar, 1 substitution per 100 nt positions. 
Table 1 and in the species description. The major cellular fatty acid methyl esters of strains MC- $246^{\mathrm{T}}$ and MC-247 and of the reference strains tested were anteiso- $\mathrm{C}_{17: 0}$, anteiso$\mathrm{C}_{15: 0}$, iso- $\mathrm{C}_{16: 0}$, iso- $\mathrm{C}_{17: 0}$ and iso- $\mathrm{C}_{15: 0}$ (Table 2). The DNA G $+C$ contents determined for strains MC- $246^{\mathrm{T}}$ and MC-247 were $49.3 \pm 0.6$ and $49.0 \pm 0.3 \mathrm{~mol} \%$, respectively; these values are within the range observed for members of the genus Paenibacillus (39.0-55.8 mol\%) (Takeda et al., 2002). Menaquinone MK-7 was the major respiratory quinone in both strains and the peptidoglycan was of type Al $\gamma$ (based on directly cross-linked meso-diaminopimelic acid). Chemotaxonomic characterization and the $16 \mathrm{~S}$ rRNA gene-based phylogenetic analysis confirm the affiliation of strains MC-246 ${ }^{\mathrm{T}}$ and MC-247 to the genus Paenibacillus. However, the low $16 \mathrm{~S}$ rRNA sequence similarity with other species of this genus $(\leqslant 94 \%)$ and the observation of several differences in the nutritional pattern and the production of extracellular enzymes support the exclusion of strains MC$246^{\mathrm{T}}$ and MC-247 from any species with validly published names. Strains MC- $246^{\mathrm{T}}$ and MC-247 share a $16 \mathrm{~S}$ rRNA gene sequence similarity of $99.6 \%$ and are distinguishable at the phenotypic (differences in nutritional pattern and the

Table 1. Distinctive characteristics of strains MC- $246^{\top}$ and MC-247 and the closely related species $P$. hodogayensis DSM $22253^{\top}$ and $P$. ginsengarvi DSM $18677^{\top}$

Strains: 1, MC- $246^{\mathrm{T}} ; 2$, MC-247; 3, P. hodogayensis DSM $22253^{\mathrm{T}} ; 4$, P. ginsengarvi DSM $18677^{\mathrm{T}}$. All strains tested in parallel in the present study. + , Positive; -, negative; $\mathrm{w}$, weakly positive.

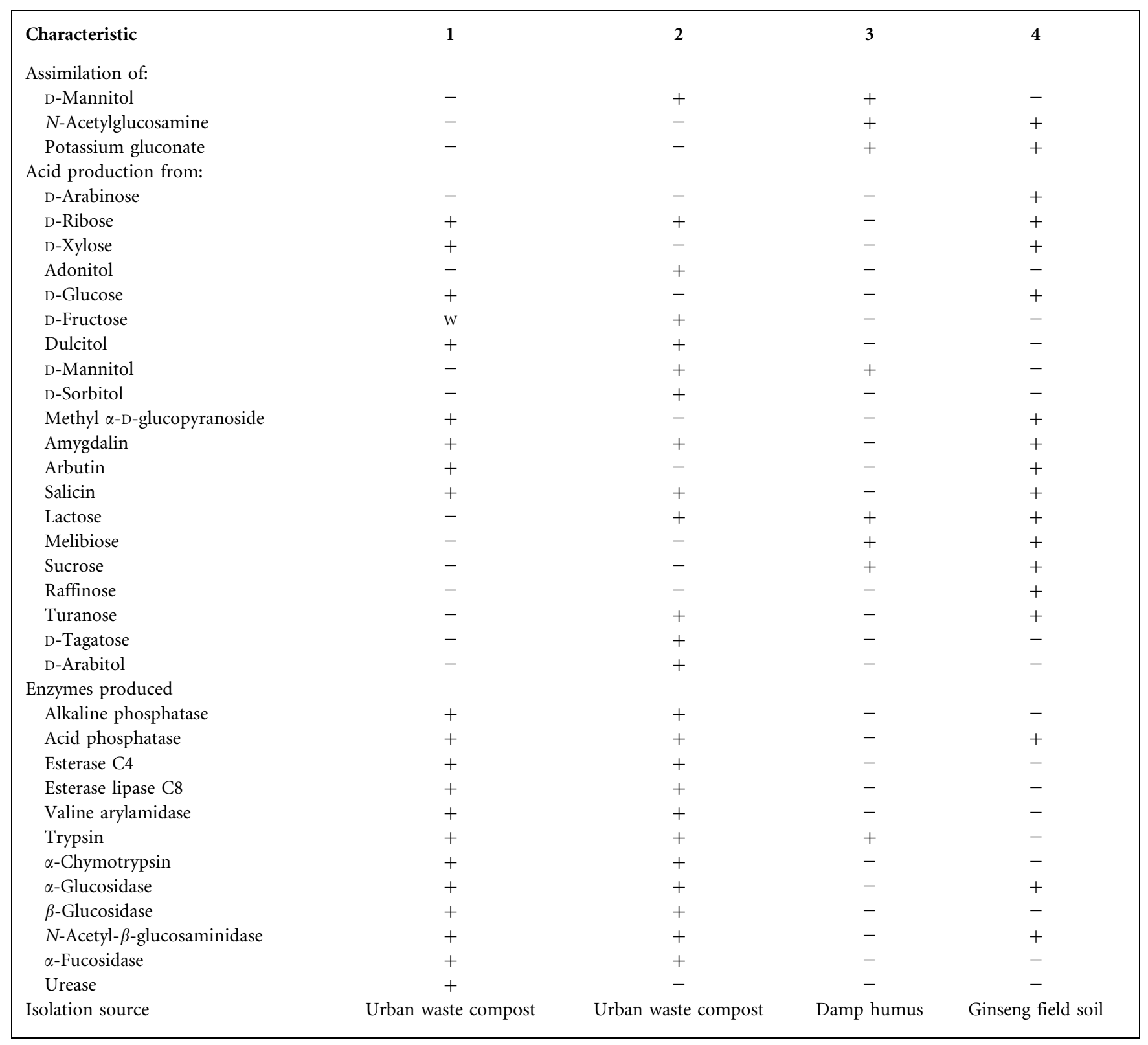


Table 2. Cellular fatty acid methyl ester composition (\%) of strains MC-246 ${ }^{\top}$, MC-247, P. hodogayensis DSM $22253^{\top}$ and $P$. ginsengarvi DSM $18677^{\top}$

Strain: 1, MC-246 ${ }^{\mathrm{T}} ; 2, \mathrm{MC}-247 ; 3, P$. hodogayensis DSM $22253^{\mathrm{T}} ; 4, P$. ginsengarvi DSM $18677^{\mathrm{T}}$. - , Not detected. All strains tested in parallel in the present study.

\begin{tabular}{|c|c|c|c|c|}
\hline Fatty acid & 1 & 2 & 3 & 4 \\
\hline $\mathrm{C}_{14: 0}$ & 0.30 & 0.41 & 1.21 & 0.49 \\
\hline $\mathrm{C}_{15: 0}$ & 2.61 & 2.62 & - & - \\
\hline$C_{16: 0}$ & 6.83 & 6.97 & 10.54 & 4.07 \\
\hline$C_{17: 0}$ & 1.43 & 1.11 & 1.39 & 1.40 \\
\hline iso- $\mathrm{C}_{14: 0}$ & 0.77 & 1.05 & 4.86 & 5.55 \\
\hline iso- $\mathrm{C}_{15: 0}$ & 9.44 & 11.19 & 18.90 & 20.34 \\
\hline iso- $\mathrm{C}_{16: 0}$ & 15.75 & 19.44 & 21.12 & 28.94 \\
\hline iso- $\mathrm{C}_{17: 0}$ & 11.05 & 11.11 & 8.23 & 8.30 \\
\hline iso- $\mathrm{C}_{18: 0}$ & 0.30 & 0.32 & - & - \\
\hline anteiso- $\mathrm{C}_{11: 0}$ & - & 0.11 & - & - \\
\hline anteiso- $\mathrm{C}_{15: 0}$ & 36.65 & 33.50 & 29.30 & 27.66 \\
\hline anteiso- $\mathrm{C}_{17: 0}$ & 14.86 & 12.18 & 3.98 & 3.25 \\
\hline $\mathrm{C}_{16: 1} \omega 7 c$ & - & - & 0.46 & - \\
\hline
\end{tabular}

ability to produce urease; Table 1) and genotypic levels (EcoRI RiboPrints and RAPD genotyping; Supplementary Figs S2 and S3). Nevertheless, the identical MALDI-TOF mass spectra (Supplementary Fig. S4) and DNA-DNA hybridization analysis, which gave values of $76-88 \%$, values that are above the threshold of $70 \%$ established for the definition of bacterial species (Wayne et al., 1987), support the inclusion of strains MC- $246^{\mathrm{T}}$ and MC-247 in the same species, for which the name Paenibacillus residui sp. nov. is proposed; strain MC- $246^{\mathrm{T}}$ is the type strain.

\section{Description of Paenibacillus residui sp. nov.}

Paenibacillus residui (re.si'du.i. L. n. residuum leavings, scraps, residues; L. gen. n. residui of leavings, scraps, residues).

Cells may stain Gram-positive or Gram-negative and are motile rods $(1.4-1.6 \mu \mathrm{m}$ long and $0.5 \mu \mathrm{m}$ wide). Polar flagella may be observed and oval spores are positioned centrally in swollen sporangia. Colonies are translucent and irregular on PCA after $48 \mathrm{~h}$ of incubation. Catalase- and oxidase-positive. Growth occurs at $25-50{ }^{\circ} \mathrm{C}$, at $\mathrm{pH}$ 7-9 and in up to $2 \% \mathrm{NaCl}$, with optimal growth at about $37{ }^{\circ} \mathrm{C}$, pH 7 and $1 \% \mathrm{NaCl}$. Growth does not occur in an anaerobic atmosphere and nitrate is not reduced. Citrate is not used, and $\mathrm{H}_{2} \mathrm{~S}$, indole and acetoin are not produced. Urease activity is variable. Glucose is not fermented. Gelatin, starch, Tween 80 and casein are not hydrolysed. Aesculin is hydrolysed. Acid and alkaline phosphatase, esterase C4, esterase lipase C8, leucine and valine arylamidase, trypsin, $\alpha$-chymotrypsin, naphthol-AS-BIphosphohydrolase, $\beta$-galactosidase, $\alpha$-glucosidase, $\beta$-glucosidase, $N$-acetyl- $\beta$-glucosaminidase and $\alpha$-fucosidase are produced. Arginine dihydrolase, lysine and ornithine decarboxylase, tryptophan deaminase, lipase $\mathrm{C} 14$, cystine arylamidase, $\alpha$-galactosidase, $\beta$-glucuronidase and $\alpha$-mannosidase are not produced. The sole carbon sources assimilated are D-glucose, maltose, D-ribose, D-fructose, methyl $\alpha$-D-glucopyranoside, amygdalin, arbutin, salicin, cellobiose, trehalose, gentiobiose, turanose and D-tagatose. The following are not assimilated: L-arabinose, D-mannose, $\mathrm{N}$-acetylglucosamine, potassium gluconate, caprate, adipate, malate, citrate, phenylacetate, glycerol, D-arabinose, Larabinose, $\mathrm{D}$-xylose, $\mathrm{L}$-xylose, methyl $\beta$-D-xylopyranoside, D-galactose, L-sorbose, L-rhamnose, inositol, D-sorbitol, methyl $\alpha$-D-mannopyranoside, lactose, melibiose, inulin, melezitose, raffinose, starch, glycogen, xylitol, D-lyxose, D-fucose, L-fucose, L-arabitol, potassium 2-ketogluconate and potassium 5-ketogluconate. Acid is produced from glycerol, D-fructose, D-ribose, dulcitol, amygdalin, salicin, cellobiose, maltose, trehalose and gentiobiose. Acid is not produced from erythritol, D-arabinose, L-arabinose, L-xylose, methyl $\beta$-D-xylopyranoside, D-galactose, D-mannose, L-sorbose, L-rhamnose, inositol, methyl $\alpha$-D-mannopyranoside, $\mathrm{N}$-acetylglucosamine, melibiose, sucrose, inulin, melezitose, raffinose, starch, glycogen, xylitol, Dlyxose, D-fucose, L-fucose, L-arabitol, potassium gluconate, potassium 2-ketogluconate or potassium 5-ketogluconate. Variable for the assimilation of D-mannitol, erythritol, adonitol, dulcitol, sucrose and D-arabitol, and for acid production from D-xylose, adonitol, D-glucose, D-mannitol, D-sorbitol, methyl $\alpha$-D-glucopyranoside, arbutin, lactose, turanose, D-tagatose and D-arabitol. Resistant to cephalothin $(30 \mu \mathrm{g})$, ceftazidime $(30 \mu \mathrm{g})$, colistin sulfate $(50 \mu \mathrm{g})$ and streptomycin $(10 \mu \mathrm{g})$. Susceptible to meropenem $(10 \mu \mathrm{g})$, amoxicillin $(25 \mu \mathrm{g})$, gentamicin $(10 \mu \mathrm{g})$, ciprofloxacin $(5 \mu \mathrm{g})$, SXT (sulfamethoxazole/trimethoprim, $23.75 / 1.25 \mu \mathrm{g})$, tetracycline $(30 \mu \mathrm{g})$, ticarcillin $(75 \mu \mathrm{g})$ and sulfamethoxazole $(25 \mu \mathrm{g})$. The predominant cellular fatty acids are anteiso- $\mathrm{C}_{15: 0}$, iso- $\mathrm{C}_{15: 0}$, iso- $\mathrm{C}_{16 \text { :0 }}$, anteiso- $\mathrm{C}_{17: 0}$ and iso- $\mathrm{C}_{17: 0}$ and the major respiratory quinone is MK-7. The cell wall peptidoglycan is of the Al $\gamma$ type (directly cross-linked meso-diaminopimelic acid). The DNA $\mathrm{G}+\mathrm{C}$ content of the type strain is $49 \mathrm{~mol} \%$.

The type strain is $\mathrm{MC}-246^{\mathrm{T}}\left(=\mathrm{DSM} 22072^{\mathrm{T}}=\mathrm{CCUG}\right.$ $57263^{\mathrm{T}}$ ), isolated from municipal urban waste compost.

\section{Acknowledgements}

We acknowledge the excellent technical assistance of Gabriele Pötter (DSMZ) in the analysis of the cellular fatty acids.

\section{References}

Ash, C., Priest, F. G. \& Collins, M. D. (1993). Molecular identification of rRNA group 3 bacilli (Ash, Farrow, Wallbanks and Collins) using a PCR probe test. Proposal for the creation of a new genus Paenibacillus. Antonie van Leeuwenhoek 64, 253260.

Bruce, J. (1996). Automated system rapidly identifies and characterizes microorganisms in food. Food Technol 50, 77-81. 
Cashion, P., Holder-Franklin, M. A., McCully, J. \& Franklin, M. (1977). A rapid method for the base ratio determination of bacterial DNA. Anal Biochem 81, 461-466.

De Ley, J., Cattoir, H. \& Reynaerts, A. (1970). The quantitative measurement of DNA hybridization from renaturation rates. Eur $J$ Biochem 12, 133-142.

Euzéby, J. P. (1997). List of bacterial names with standing in nomenclature: a folder available on the Internet. Int J Syst Bacteriol 47, 590-592. http://www.bacterio.net

Fehr, M. (2007). Confirming decentralised composting as a definite option in urban waste management. Int J Environ Technol Manag 7, 274-285.

Ferreira da Silva, M., Tiago, I., Veríssimo, A., Boaventura, A. R., Nunes, O. C. \& Manaia, C. M. (2006). Antibiotic resistance of enterococci and related bacteria in an urban wastewater treatment plant. FEMS Microbiol Ecol 55, 322-329.

Ferreira da Silva, M., Vaz-Moreira, I., Gonzalez-Pajuelo, M., Nunes, O. C. \& Manaia, C. M. (2007). Antimicrobial resistance patterns in Enterobacteriaceae isolated from an urban wastewater treatment plant. FEMS Microbiol Ecol 60, 166-176.

Huß, V. A. R., Festl, H. \& Schleifer, K. H. (1983). Studies on the spectrophotometric determination of DNA hybridization from renaturation rates. Syst Appl Microbiol 4, 184-192.

Jukes, T. H. \& Cantor, C. R. (1969). Evolution of protein molecules. In Mammalian Protein Metabolism, vol. 3, pp. 21-132. Edited by H. N. Munro. New York: Academic Press.

Kämpfer, P. \& Kroppenstedt, R. M. (1996). Numerical analysis of fatty acid patterns of coryneform bacteria and related taxa. Can $J$ Microbiol 42, 989-1005.

Mesbah, M., Premachandran, U. \& Whitman, W. B. (1989). Precise measurement of the $\mathrm{G}+\mathrm{C}$ content of deoxyribonucleic acid by highperformance liquid chromatography. Int J Syst Bacteriol 39, 159-167.

Murray, R. G. E., Doetsch, R. N. \& Robinow, F. (1994). Determinative and cytological light microscopy. In Methods for General and Molecular Bacteriology, pp. 21-41. Edited by P. Gerhardt, R. G. E. Murray, W. A. Wood \& N. R. Krieg. Washington, DC: American Society for Microbiology.

Rhuland, L. E., Work, E., Denman, R. F. \& Hoare, D. S. (1955). The behavior of the isomers of $\alpha, \varepsilon$-diaminopimelic acid on paper chromatograms. J Am Chem Soc 77, 4844-4846.
Schleifer, K. H. \& Kandler, O. (1972). Peptidoglycan types of bacterial cell walls and their taxonomic implications. Bacteriol Rev 36, 407-477.

Schleifer, K. H. \& Seidl, P. H. (1985). Chemical composition and structure of murein. In Chemical Methods in Bacterial Systematics, pp. 201-215. Edited by M. Goodfellow \& D. E. Minnikin. London: Academic Press.

Shida, O., Takagi, H., Kadowaki, K., Nakamura, L. K. \& Komagata, K. (1997). Transfer of Bacillus alginolyticus, Bacillus chondroitinus, Bacillus curdlanolyticus, Bacillus glucanolyticus, Bacillus kobensis, and Bacillus thiaminolyticus to the genus Paenibacillus and emended description of the genus Paenibacillus. Int J Syst Bacteriol 47, 289-298.

Smibert, R. M. \& Krieg, N. R. (1994). Phenotypic characterization. In Methods for General and Molecular Bacteriology, pp. 607-654. Edited by P. Gerhardt, R. G. E. Murray, W. A. Wood \& N. R. Krieg. Washington, DC: American Society for Microbiology.

Takeda, M., Kamagata, Y., Shinmaru, S., Nishiyama, T. \& Koizumi, J. (2002). Paenibacillus koleovorans sp. nov., able to grow on the sheath of Sphaerotilus natans. Int J Syst Evol Microbiol 52, 1597-1601.

Tiago, I., Teixeira, I., Silva, S., Chung, P., Veríssimo, A. \& Manaia, C. M. (2004). Metabolic and genetic diversity of mesophilic and thermophilic bacteria isolated from composted municipal sludge on poly- $\varepsilon$-caprolactones. Curr Microbiol 49, 407-414.

Tindall, B. J. (1989). Fully saturated menaquinones in the archaebacterium Pyrobaculum islandicum. FEMS Microbiol Lett 60, 251-254.

Tóth, E. M., Schumann, P., Borsodi, A. K., Kéki, Z., Kovács, A. L. \& Márialigeti, K. (2008). Wohlfahrtiimonas chitiniclastica gen. nov., sp. nov., a new gammaproteobacterium isolated from Wohlfahrtia magnifica (Diptera: Sarcophagidae). Int J Syst Evol Microbiol 58, 976-981.

Vaz-Moreira, I., Nobre, M. F., Nunes, O. C. \& Manaia, C. M. (2007). Gulbenkiania mobilis gen. nov., sp. nov., isolated from treated municipal wastewater. Int J Syst Evol Microbiol 57, 1108-1112.

Vaz-Moreira, I., Silva, E., Manaia, C. M. \& Nunes, O. C. (2008). Diversity of bacterial isolates from commercial and homemade composts. Microb Ecol 55, 714-722.

Wayne, L. G., Brenner, D. J., Colwell, R. R., Grimont, P. A. D., Kandler, O., Krichevsky, M. I., Moore, L. H., Moore, W. E. C., Murray, R. G. E. \& other authors (1987). International Committee on Systematic Bacteriology. Report of the ad hoc committee on reconciliation of approaches to bacterial systematics. Int J Syst Bacteriol 37, 463-464. 